\title{
Kemampuan Koneksi Matematis Siswa Tipe Sensing-Intuiting dalam Menyelesaikan Soal Olimpiade
}

\author{
Roy Agung Cahya Putra ${ }^{1 *}$, Azhar Syarifuddin² \\ ${ }^{1,2}$ STKIP Al-Hikmah, Kota Surabaya, Jawa Timur 60232, Indonesia \\ Pengiriman: 20 Januari 2019; Diterima: 23 April 2019; Publikasi: 30 April 2019 \\ DOI: https://doi.org/10.31629/jg.v4i1.899
}

\begin{abstract}
Abstrak
Koneksi matematis merupakan salah satu kemampuan yang harus dimiliki siswa dalam mempelajari matematika di sekolah. Melalui koneksi matematis, siswa dapat lebih mudah dalam menyelesaikan soal terutama soal olimpiade. Hal tersebut dikarenakan dalam pengerjaan, soal olimpiade membutuhkan penalaran dan pemahaman konsep serta hubungan antar konsep secara mendalam. Penelitian ini mengangkat tentang kemampuan koneksi matematis berdasarkan tipe kepribadian Sensing-Intuiting, karena tipe Sensing cenderung pada pengetahuan prosedural sedangkan Intuiting cenderung pada pemrosesan data berdasarkan pola dan hubungan secara konseptual dan melihat kemungkinan yang terjadi. Tujuan dari penelitian ini adalah mendeskripsikan kemampuan koneksi matematis siswa berkepribadian Sensing - Intuiting dalam menyelesaikan soal olimpiade. Jenis penelitian ini adalah deskriptif kualitatif, penelitian ini dilaksanakan di salah satu SMP yang ada di Surabaya dengan subjek sebanyak 2 siswa yaitu 1 siswa tipe Sensing dan 1 siswa tipe Intuiting. Subjek dipilih menggunakan angket Myers-Briggs Type Indicator (MBTI) dan diuji dengan 3 soal olimpiade yang kemudian diwawancara. Hasil analisis menunjukkan bahwa siswa berkepribadian Sensingmemiliki kemamuan koneksi matematis sedang dengan rata-rata nilai adalah 3, sedangkan siswa berkepribadian Intuiting memiliki kemampuan koneksi matematis tinggi denga rata-rata nilai adalah 4,6 .
\end{abstract}

Kata kunci: koneksi matematis; kepribadian; sensing, intuiting, soal olimpiade

\begin{abstract}
Mathematical connection is one of the abilities that students must have in learning mathematics at school. Through mathematical connection, students can more easily solve problems, especially Olympiad problems. This is because in progress, Olympiad problems require reasoning and understanding concepts and relationships between concepts in depth. This study raises the ability of mathematical connection based on sensing-intuiting personality types, because sensing types tend to master procedural knowledge while intuiting tends to process data based on patterns and relationships conceptually and see possibilities that occur. The purpose of this study is to describe the mathematical connection ability of students with sensing - intuiting personality in completing Olympiad problems. This type of research is qualitative descriptive. This research was conducted in one of the junior high schools in Surabaya with 2 students as subjects, namely 1 sensing typed student and 1 intuiting typed student. Subjects were selected using the Myers-Briggs Type Indicator (MBTI) questionnaire and tested with 3 Olympiad problems which were then interviewed. The results of the analysis show that student with sensing personality have a moderate mathematical connection ability with an average value of 3 , while intuiting student have a high mathematical connection ability with an average score of 4.6.
\end{abstract}

Keywords: mathematical connection; personality; sensing; intuiting; olympiad questions

*Penulis Korespondensi

Email Address: royagung98@gmail.com

Handphone : : +62 87777091148 


\section{JURNAL GANTANG. April 2019; IV(1): 61 - 70 \\ p-ISSN. 2503-0671 \\ e-ISSN. 2548-5547}

\section{Pendahuluan}

Matematika adalah ilmu yang memiliki karakter tertentu, salah satunya adalah saling berkaitan satu sama lain. The National Council of Teacher of Mathematics/NCTM (2000) mengatakan bahwa standar kemampuan dasar matematika ada lima, yaitu: pemecahan masalah (problem solving), penalaran dan pembuktian (reasoning and proof), komunikasi (communications), koneksi (connections), dan representasi (representation). Koneksi matematis merupakan salah satu kemampuan yang harus dimiliki siswa dalam mempelajari matematika di sekolah, karena dalam pembelajaran matematika setiap konsep berkaitan dengan konsep lainnya. Lasmawati (2011) berpendapat bahwa melalui koneksi matematis, wawasan siswa akan semakin terbuka yang kemudian menimbulkan sikap positif terhadap matematika itu sendiri. Dengan demikian siswa akan memiliki kemampuan lebih dalam memecahkan masalah dan mengambil keputusan secara logis dan berdasarkan pemikiran yang cerdas. Oleh karena itu, dalam menyelesaikan masalah matematika, siswa haruslah memiliki kemampuan koneksi matematis yang baik.

Kemampuan koneksi matematis adalah kemampuan seseorang dalam menyajikan hubungan internal dan eksternal dalam matematika, hubugan dengan disiplin ilmu lain, dan hubungan dengan kehidupan sehari-hari (Rohendi \& Dulpaja, 2013). Indikator koneksi matematis siswa menurut NCTM (2000) adalah

1. Mengenali dan menggunakan hubungan antar ide -ide matematika.

2. Memahami bagaimana ide-ide matematika saling berhubungan dan membangun satu sama lain untuk menghasilkan kesatuan yang utuh.

3. Mengenali dan mengaplikasikan matematika ke dalam konteks di luar matematika.

Tujuan koneksi matematis adalah untuk membentuk persepsi siswa dengan melihat matematika terintegrasi dengan dunia nyata dan mengenal manfaat matematika baik di dalam ataupun diluar sekolah (Warih, Parta, \& Rahardjo, 2016). Beberapa penelitian menyatakan bahwa kemampuan koneksi matematis siswa perlu ditingkatan. Seperti Lestari (2014) yang mengungkapkan bahwa kemampuan koneksi matematis siswa SMP kelas VIII masih tergolong rendah dan sedang. Penelitian lainnya menyimpulkan bahwa kemampuan koneksi matematis siswa SMP kelas VIII masih rendah (Sudirman, 2017). Penelitian relevan lainnya menyimpulkan bahwa kemampuan koneksi matematis siswa SMP kelas VIII pada materi SPLDV masih rendah (Nugraha, 2018). Berdasarkan beberapa penelitian tersebut, dapat ditunjukkan bahwa kemampuan koneksi matematis penting untuk dikembangkan pada siswa, sehingga peneliti tetarik untuk mengkaji lebih dalam mengenai kemampuan koneksi matematis siswa.

Salah satu soal matematika yang membutuhkan penalaran dan kemampuan koneksi adalah soal olimpiade. Penting bagi siswa dalam memahami keterkaitan (koneksi) materi pada matematika karena mayoritas soal olimpiade tidak dapat diselesaikan dengan hanya 1 prosedur atau 1 konsep. Hal ini sesuai dengan pendapat Sugiman (2008) bahwa keterkaitan antar konsep dalam matematika memiliki peran yang sangat penting dalam mempelajari matematika itu sendiri. Melalui koneksi, siswa dapat memahami keterkaitan antar topik yang kemudian akan memudahkan siswa dalam mempelajari matematika itu sendiri. Sehingga siswa tidak harus berorientasi pada hafalanhafalan rumus yang membuat siswa menjadi jenuh.

Kemampuan koneksi matematis siswa dipengaruhi oleh kecemasan belajar (Anita, 2014). Kecemasan belajar dipengaruhi oleh faktor tipe kepribadian seseorang (Trujillo \& Hadfield, 1999). Oleh karena itu, kepribadian siswa dapat mempengaruhi kemampuan koneksi matematis siswa. Kepribadian seseorang berdasarkan Myers-Briggs Type Indicator (MBTI) terdapat 4 dimensi yang saling berlawanan yaitu introvert-ekstrovert, sensingintuition, thinking-feeling, dan judgingperceiving (Fadhilla, Ro'is, \& Syarif, 2017).

Introvert adalah tipe pribadi yang memperoleh energi dari dalam diri, sedangkan 
ekstrovert adalah tipe pribadi yang memperoleh energi dari dunia luar. Sensing adalah tipe pribadi yang memproses data berdasarkan fakta yang konkret, praktis dan realistis, sedangkan intuition adalah tipe pribadi yang memroses data berdasarkan pola dan hubungan secara konseptual dan melihat berbagai kemungkinan yang terjadi. Thinking adalah tipe pribadi yang menggunakan logika dan analisis dalam mengambil keputusan, sedangkan Feeling adalah tipe pribadi yang melibatkan perasaan dan empati dalam mengambil keputusan. Judging adalah tipe pribadi yang berorientasi pada rencana yang sistematis, sedangkan Perceiving adalah tipe pribadi yang bersifat spontan, fleksibel dan adaptif dalam bertindak.

Banyak penelitian pendidikan matematika yang menggunakan tipe kepribadian introvert-ekstrovert, seperti pada Lestari (2016) yang membahas proses berpikir siswa dalam memecahkan masalah berdasarkan tipe kepribadian introvert dan ekstrovert. Paneo (2007) membahas tentang pengaruh umpan balik evaluasi formatif dan kepribadian siswa terhadap hasil belajar, tipe kepribadian yang digunakan adalah tipe introvert dan ekstrovert. Qomariah (2016) membahas tentang profil pemahaman siswa SMA dalam memecahkan masalah persamaan kuadrat ditinjau dari perbedaan kepribadian ekstrovert dan introvert. Belum banyak penelitian yang menggunakan tipe kepribadian sensing dan intuition. Peneliti memilih tipe kepribadian sensing dan intuition, karena dimensi ini melihat bagaimana siswa memperoleh informasi. Sensing adalah tipe kepribadian yang memproses data berdasarkan fakta yang konkrit dan realistis. Syafmen (2014) menambahkan bahwa kepribadian sensing berkaitan dengan pengetahuan prosedural. Sedangkan intuition tipe pribadi yang memproses data berdasarkan pola dan hubungan secara konseptual dan melihat kemungkinan yang terjadi. Oleh karena itu, peneliti tertarik untuk meneliti siswa dengan tipe kepribadian sensing-intuiting.

Berdasarkan uraian diatas peneliti ingin menganalisis koneksi matematis siswa berkepribadian sensing-intuiting dalam menyelesaikan soal olimpiade. Tujuan dari penelitian ini adalah untuk mendeskripsikan kemampuan koneksi matematis siswa berkepribadian sensing-intuiting dalam menyelesaikan soal olimpiade.

\section{Metode Penelitian}

Penelitian ini menggunakan pendekatan deskriptif kualitatif, karena sesuai dengan tujuan penelitian ini yaitu mendeskripsikan kemampuan koneksi matematis siswa berkepribadian sensing - intuiting dalam menyelesaikan soal olimpiade.

Penelitian ini dilaksanakan pada salah satu SMP yang ada di kota Surabaya pada bulan Oktober - November 2018. Subjek penelitian ini adalah 2 siswa kelas VIII di sekolah tersebut dengan kriteria 1 siswa berkepribadian sensing dan 1 siswa berkepribadian intuiting. Siswa bersangkutan adalah siswa yang memiliki kemampuan matematika tinggi. Subjek berkepribadian sensing dan intuiting dipilih dengan menggunakan angket Myers-Briggs Type Indicator (MBTI) yang sudah tervalidasi, sedangkan untuk menentukan tingkat kemampuan siswa adalah berdasarkan nilai Ujian Tengah Semester (UTS) siswa dan rekomendasi guru.

Instrumen yang digunakan dalam penelitian ini terdiri dari instrumen utama yaitu peneliti dan instrumen pendukung yaitu angket Myers-Briggs Type Indicator (MBTI) yang terdiri dari 15 poin untuk megklasifikasikan siswa berkepribadian sensing dan siswa berkepribadian intuiting, dan 3 butir soal olimpiade yang diambil dari OSP 2003, OSP 2004 dan OSP 2006, yaitu sebagai berikut :

1. Jika $a+b=1, b+c=2$, dan $c+a=3$ maka $a+b+c=\cdots($ OSP 2014)

2. Dalam suatu kelas, $3 / 5$ bagian siswanya adalah wanita. $\mathrm{Ke}$ dalam kelas tersebut ditambahkan 5 siswa pria dan 5 siswa wanita. Sekarang 3/7 bagian siswanya adalah pria. Berapa banyakkah siswa dalam kelas mula-mula? (OSP 2003)

3. Diberikan segitiga $P Q R$ siku-siku di $Q$. Jika panjang $P Q$ adalah $x+4$, panjang $Q R$ adalah $3 x+2$, dan panjang $P R$ adalah $3 x+$ 4 , maka panjang $Q R$ adalah... (OSP 2006) 
JURNAL GANTANG. April 2019; IV(1): 61 - 70

p-ISSN. 2503-0671

e-ISSN. 2548-5547

Prosedur yang digunakan pada penelitian ini terdiri dari tiga tahap, yaitu: tahap persiapan, tahap pelaksanaan, dan tahap analisis data.

Tahap persiapan, meliputi

1. Menyusun desain penelitian, meliputi Pendahuluan, kajian teori, metode penelitian, dan rancangan instrument penelitian.

2. Melakukan diskusi bersama pembimbing terkait instrument penelitian berupa angket Myers-Briggs Type Indicator (MBTI), dan tes soal olimpiade.

3. Menentukan jadwal penelitian.

Tahap pelaksanaan meliputi,

1. Memberikan angket Myers-Briggs Type Indicator (MBTI) untuk megklasifikasikan siswa berkepribadian sensing dan siswa berkepribadian intuiting.

2. Memberikan soal olimpiade kepada siswa, terdiri dari 3 butir soal olimpiade yang diambil dari OSP 2003, OSP 2004 dan OSP 2006. Tes soal olimpiade dilakukan dengan tujuan untuk mengetahui sejauh mana ketuntasan pengerjaan dan kemampuan koneksi matematis melalui indikator yang sudah di tentukan.

3. Wawancara dengan menggunakan metode interview tidak terstruktur.

4. Triangulasi dimana menurut Moleong (2009) merupakan teknik pemeriksaan keabsahan data yang memanfaatkan sesuatu yang lain. Triangulasi yang digunakan adalah triangulasi waktu dilakukan untuk pengujian kredibilitas data (derajat kepercayaan) yang dilakukan dengan cara pengecekan pada hasil wawancara dalam waktu atau situasi yang berbeda.

Tahap analisis terdiri dari reduksi data, menganalisis jawaban siswa, mengolah data yang diperoleh, dan menarik kesimpulan. Dalam penelitian ini digunakan sejumlah indikator kemampuan koneksi matematika. Indikator kemampuan koneksi matematika bermakna petunjuk dalam menganalisis fenomena koneksi matematika. Kemampuan koneksi matematika yang ditelaah dalam proses analisis memuat sejumlah indikator kemampuan koneksi matematika yang dapat dilihat pada tabel berikut. Indikator kemampuan koneksi matematika tersebut sebagai berikut.

Tabel 1.

Indikator kemampuan koneksi matematika

\begin{tabular}{clc} 
No. & \multicolumn{1}{c}{ Aspek Koneksi Matematika } & Skor \\
\hline 1. & $\begin{array}{l}\text { Mengetahui hubungan diantara } \\
\text { ide-ide matematika }\end{array}$ & 1 \\
\hline 2. & $\begin{array}{l}\text { Menerapkan hubungan diantara } \\
\text { ide-ide matematika }\end{array}$ & 1 \\
\hline 3. & $\begin{array}{l}\text { Memahami hubungan diantara } \\
\text { ide-ide matematika }\end{array}$ & 1 \\
\hline & $\begin{array}{l}\text { Mengetahi hubungan antara } \\
\text { bidang matematika dengan bidang } \\
\text { ilmu lain }\end{array}$ & 1 \\
\hline & $\begin{array}{l}\text { Menerapkan hubungan antara } \\
\text { bidang matematika dengan bidang } \\
\text { ilmu lain }\end{array}$ & 1
\end{tabular}

Sedangkan kriteria pengklasifikasian kemampuan koneksi matematika dapat dilihat pada tabel berikut

Tabel 2.

Klasifikasi kemampuan koneksi matematika

\begin{tabular}{ccc} 
No. & Total Nilai & Kategori \\
\hline 1. & $0-1$ & Rendah \\
\hline 2 & $2-3$ & Sedang \\
\hline 3 & $4-5$ & Tinggi
\end{tabular}

\section{Hasil dan Pembahasan}

Hasil penelitian yang diperoleh berupa hasil pengerjaan siswa dan hasil wawancara koneksi matematis. Data tersebut kemudian dianalisis sehingga diperoleh kesimpulan tentang kemampuan koneksi matematis siswa tipe sensing-intuiuting dalam menyelesaikan soal olimpiade.

Subjek berkepribadian intuiting

1. Soal nomor 1

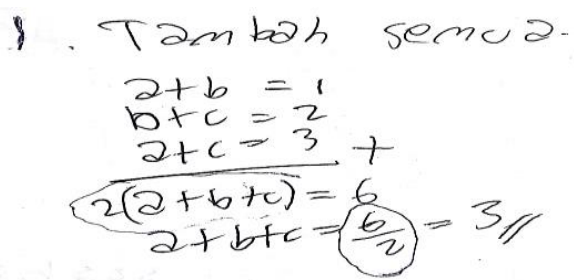

Gambar 1. Jawaban JN pada soal nomor 1. 
Setelah mengecek sebanyak 3 kali, JN menentukan bahwa soal nomor 1 berhubungan dengan beberapa konsep matematika yaitu: Aljabar, PLSV, danSPLDV.

Transkrip wawancara soal nomor 1

$\mathrm{P}$ : menurut anda apakah ada hubungan antara soal dengan bab matematika lain?

JN : menurut saya soal ini berhubungan dengan Aljabar, PLSV, SPLDV

JN menerapkan konsep PLSV dan SPLDV Untuk menyelesaikan soal nomor 1. Pada tahap awal JN melakukan penjumlahan dari setiap persamaan yang kemudian menghasilkan 1 persamaan baru yaitu $2(a+b+c)=6$. Setelah itu, menggunakan konsep PLSV JN dapat menenukan nilai dari $\mathrm{a}+\mathrm{b}+\mathrm{c}$ yaitu 3 . Untuk memperkuat pemahamannya, JN mampu membuat contoh soal lain yang berkaitan dengan soal nomor 1 dan menjelaskan bagaimana cara menyelesaikan soal tersebut.

JN membaca ulang dan mencoba mengingat kembali hubungan soal dengan disiplin ilmu lain. JN menetukan bahwa soal berhubungan dengan mata pelajaran lain yaitu fisika, namun JN masih belum paham bagaimana penerapan keterkaitan dari kedua mata pelajaran yakni matematika dan fisika.

Berdasarkan hasil tes dan hasil wawancara dapat disimpulkan bahwa pada soal nomor 1, dalam analisis kemampuan koneksi matematis JN memenuhi 4 indikator, JN tidak bisa memenuhi indikator "Menerapkan hubungan antara bidang matematika dengan bidang ilmu lain" karena tidak mampu menjelaskan tentang penerapan dari hubungan yang disebutkan. Dapat disimpulkan bahwa kemampuan koneksi matematis JN pada soal nomor 1 tergolong tinggi.

\section{Soal nomor 2}

Jawaban atas soal nomor 2 dapat dilihat pada gambar 2. Setelah mengecek sebanyak 2 kali, JN menentukan bahwa soal nomor 2 berhubungan dengan beberapa konsep matematika yaitu: aljabar, pecahan dan Perbandingan. JN menerapkan konsep Aljabar dan pecahan untuk membuat suatu pemisalan

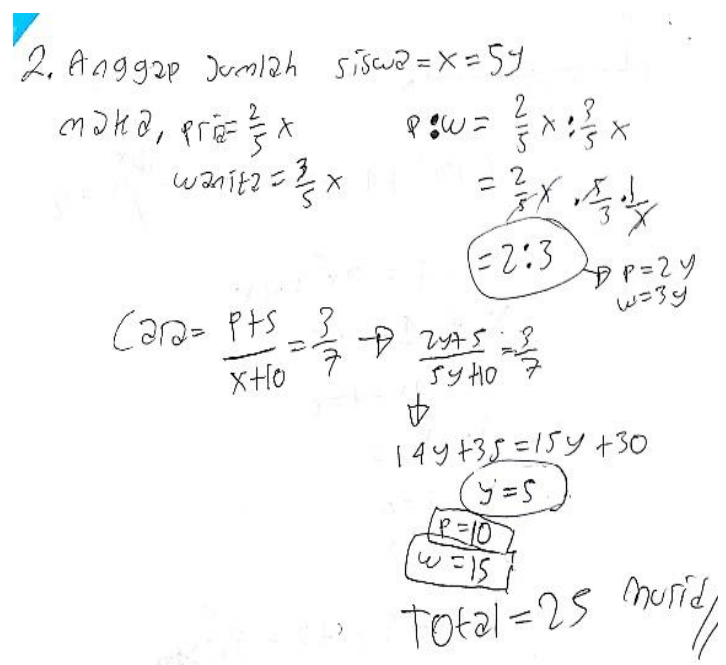

Gambar 2. Jawaban JN pada soal nomor 2

antara banyaknya pria dan wanita.

Setelah mendapatkan pemisalan, JN menggunakan konsep perbandingan yaitu dengan membandingkan antara pria dan wanita. Untuk menyelesaikan soal nomor 2 JN melanjutkan dengan konsep penjumlahan pecahan dan perbandingan hingga mendapatkan jawaban yaitu banyak pria adalah 15 dan banyak wanita adalah 10 sehingga total jumlah murid adalah 25 siswa. Setelah itu, Untuk memperkuat pemahamannya, JN membuat contoh soal lain yang berkaitan dengan soal nomor 2 dan menjelaskan bagaimana cara menyelesaikan soal tersebut.

Transkrip wawancara soal nomor 2

$\mathrm{P}$ : untuk memastikan pemahaman anda, bisakah anda membuatkan contoh lain yang berhubungan dengan soal nomor 2 kemudian menjelaskan cara mengerjakannya?

JN : bisa gak ya? emmmmm... akan saya coba (kemudian menyajikan sebuah contoh lalu menjelaskannya).

JN mencoba mengingat kembali hubungan soal nomor 2 dengan disiplin ilmu lain. JN menetukan bahwa soal berhubungan dengan mata pelajaran lain yaitu fisika. Penerapan hubungan antar kedua mata pelajaran ini terletak pada konsep perbandingan. JN mengatakan bahwa di bidang fisika juga sering menggunakan konsep perbandingan, seperti 
JURNAL GANTANG. April 2019; IV(1): 61 - 70

p-ISSN. 2503-0671

e-ISSN. 2548-5547

perbandingan skala termometer dan lain sebagainya.

Transkrip wawancara soal nomor2

$\mathrm{P}$ : menurut anda seperti apakah penerapan hubungan antara soal nomor 2 dengan fisika?

JN : kan di soal nomor 2 ini menggunakan pecahan dan perbandingan. Kan di fisika juga ada yang menggunakan perbandingan.

$\mathrm{P}$ : contohnya?

JN : contohnya.... Ini, perbandingan skala antara termometer Celcius, Reaumur dan Fahrenheit.

Berdasarkan hasil tes dan hasil wawancara dapat disimpulkan bahwa pada soal nomor 2, dalam analisis kemampuan koneksi matematis JN memenuhi semua indikator yaitu sebanyak 5 indikator. Dapat disimpulkan bahwa kemampuan koneksi matematis JN pada soal nomor 2 tergolong tinggi.

3. Soal nomor 3

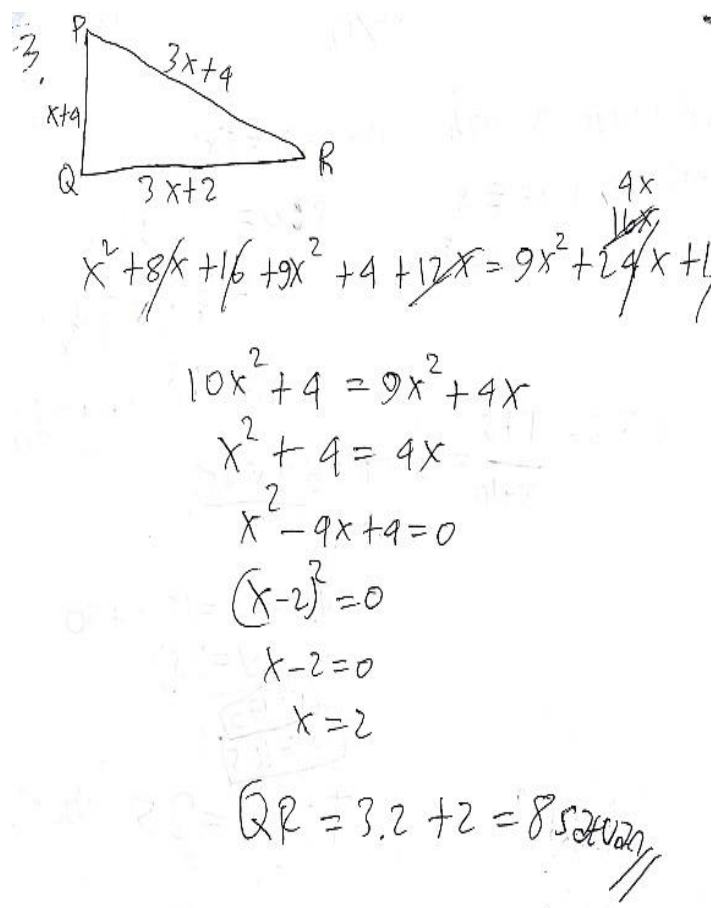

Gambar 4. Jawaban JN pada soal nomor 3.

Setelah mengecek sebanyak 3 kali, JN menentukan bahwa soal nomor 3 berhubungan dengan beberapa konsep matematika yaitu: aljabar, segitiga, dan teorema Pythagoras.
Pada soal nomor 3, diawal JN menggambarkan segitiga beserta panjang sisisisinya yaitu panjang $P Q$ adalah $x+4$, panjang $Q R$ adalah $3 x+2$ dan panjang $P R$ adalah $3 x+$ 4. Kemudian menerapkan konsep teorema Pythagoras yang menghasilkan sebuah persamaan kuadrat, kemudian menggunakan pemfaktoran sehingga didapatkan nilai dari $x$ yaitu 2 . Setelah itu, nilai $x$ yang sudah diketahui disubstitusikan ke dalam sisi yang ditanyakan pada soal, yaitu panjang $Q R$, maka didapatkan panjang $Q R$ adalah 8 satuan. Selanjutnya, Untuk memastikanbahwa JN sudah memahami koneksi yang sudah disebutkan dan diterapkan, JN membuat contoh soal yang serupa dan menjelaskan bagaimana cara menyelesaikan soal tersebut.

Setelah itu, JN memikirkan kembali hubungan antara soal dengan mata pelajaran lain. JN menentukan bahwa soal nomor 3 berhubungan dengan fisika dan berhubungan dengan di bidang pramuka. Penerapan pramuka adalah saat mengukur ketinggian sebuah tiang/pohon yaitu menggunakan cara seperti di teorema Pythagoras.

Transkrip wawancara soal nomor3

$\mathrm{P}$ : menurut anda apakah ada hubungan antara soal dengan bidang mata pelajaran lain/bidang lainnya?

JN : bidang lain? Hmmm... mungkin fisika juga ada, tentang bidang miring untuk mencari keuntungan mekanis itu, sama di pramuka juga ada.

$\mathrm{P}$ : di pramuka? seperti apakah penerapan hubungan antara soal nomor 3 dengan pramuka?

JN : yang buat menghitung tiang-tiang itu kan? Menghitung jarak, menghitung tinggi sama menghitung bayangan.

Berdasarkan hasil tes dan hasil wawancara dapat disimpulkan bahwa pada soal nomor 3, dalam analisis kemampuan koneksi matematis JN memenuhi semua indikator yaitu sebanyak 5 indikator.Dapat disimpulkan bahwa kemampuan koneksi matematis JN pada soal nomor 3 tergolong tinggi. 
Tabel 3.

Hasil Analisis Kemampuan Koneksi Matematis Siswa Berkepribadian Intuiting

\begin{tabular}{cccccccc} 
Nama & Kepribadian & Soal 1 & Soal 2 & Soal 3 & Total Skor & Rata-rata & Kategori \\
\hline JN & Intuiting & 4 & 5 & 5 & 14 & 4,6 & Tinggi
\end{tabular}

Berdasarkan hasil analisis diatas, dari 3 soal yang diberikan hampir semua soal memenuhi semua indikator yang sudah ditentukan, hanya nomor 1 yang tidak sempurna karena tidak memenuhi 1 indikator yaitu menerapkan hubungan antara bidang matematika dengan bidang ilmu lain. Hal ini menunjukkan bahwa siswa yang berkepribadian intuiting memiliki kemampuan koneksi matematis tinggi. Sesuai dengan karakter kepribadian intuiting yaitu memproses data berdasarkan pola dan hubungan secara konseptual dan melihat kemungkinan yang terjadi, maka dalam menyelesaikan soal olimpiade yang diberikan JN dapat dengan baik mengetahui, menerapkan dan memahami hubungan antar matematika dan hubungan antar matematika dengan bidang ilmu lain.

Subjek berkepribadian sensing

1. Soal nomor 1

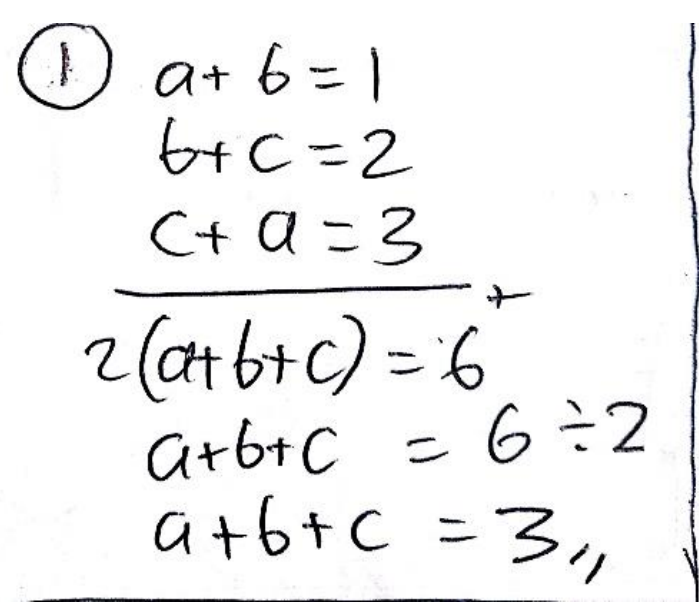

Gambar 4. Jawaban AR pada soal nomor 1.

Setelah memeriksa sebanyak 2 kali, AR menentukan bahwa soal nomor 1 berhubungan dengan beberapa konsep matematika yaitu: aljabar, PLSV, dan SPLDV.
AR menerapkan konsep PLSV dan SPLDV Untuk menyelesaikan soal nomor 1 . Pada tahap awal AR melakukan penjumlahan dari setiap persamaan yang kemudian menghasilkan 1 persamaan baru yaitu $2(a+$ $b+c)=6$. Setelah itu, menggunakan konsep PLSV,AR dapat menentukan nilai dari $a+b+$ $c$ yaitu 3. AR mampu membuat contoh soal lain yang berkaitan dengan soal nomor 1 dan menjelaskan bagaimana cara menyelesaikan soal tersebut.

AR mencoba untuk mengingat kembali hubungan soal dengan disiplin ilmu lain, namun AR merasa kurang paham tentang hubungan yang terdapat pada soal, sehingga AR tidak dapat mengetahui adanya hubungan antara soal dengan bidang ilmu lain.AR juga tidak dapat memberikan keterangan tentang penerapan soal terhadap bidang ilmu lain.

Transkrip wawancara soal nomor1

$\mathrm{P}$ : menurut anda apakah ada hubungan antara soal dengan bidang ilmu lainnya?

AR: bidang lain? Kalau itu saya kurang paham, yang saya tahu ya ini saja.

Berdasarkan hasil tes dan hasil wawancara dapat disimpulkan bahwa pada soal nomor 1, dalam analisis kemampuan koneksi matematis AR memenuhi 3 indikator. AR tidak bisa memenuhi indikator mengetahui hubungan antara bidang matematika dengan bidang ilmu lain dan menerapkan hubungan antara bidang matematika dengan bidang ilmu lain karena tidak mampu menyebutkan hubungan yang terdapat pada soal dengan bidang ilmu lain dan tidak mampu menjelaskan tentang penerapan dari hubungan tersebut. Dapat disimpulkan bahwa kemampuan koneksi matematis AR pada soal nomor 1 tergolong sedang. 
JURNAL GANTANG. April 2019; IV(1): 61 - 70

p-ISSN. 2503-0671

e-ISSN. 2548-5547

2. Soal nomor 2

$$
\begin{aligned}
& \text { (2) Wanied: Pria }=3 x: 2 x \\
& 3 x+5: 2 x+5=4 x: 3 x \\
& 3 x+5=4 x \\
& 5=4 x-3 x \\
& x=5, \rightarrow \text { Wanta + bria }=5 x=5 \times 5=25
\end{aligned}
$$

Gambar 5. Jawaban AR pada soal nomor 2.

Setelah mengecek sebanyak 1 kali, AR menentukan bahwa soal nomor 2 berhubungan dengan beberapa konsep matematika yaitu: aljabar, persamaan dan Perbandingan.

AR langsung menerapkan konsep perbandingan antara banyaknya pria dan wanita yaitu $3 x \div 2 x$, dan kemudian langsung mengggunakan persamaan sehingga diperoleh $3 x+5=4 x$ sehingga didapatkan nilai $x$ yaitu 5 , kemudian langsung menentukan jawaban yaitu 25. AR tidak mampu memberikan contoh yang serupa dengan soal nomor 2. Awalnya AR mencoba mengingat dan memikirkan, namun akhirnya tetap tidak bisa.

Berkaitan dengan hubungan antar soal dengan bidang ilmu lain, AR tidak mampu menentukan. Karena AR tidak mampu memenuhi indikator koneksi matematis yang ke 3, maka AR pun tidak dapat memenuhi indikator yang ke 4 dan ke 5.

Transkrip wawancara soal nomor 2

$\mathrm{P}$ : menurut anda apakah ada hubungan antara soal dengan bidang ilmu lainnya?

AR : emmm... kurang tau, yang saya tau ya cuma matematika.

Berdasarkan hasil tes dan hasil wawancara dapat disimpulkan bahwa pada soal nomor 2, dalam analisis kemampuan koneksi matematis AR tidak mampu memenuhi 3 indikator yaitu indikator yang ke 3, 4 dan 5 .
Dapat disimpulkan bahwa kemampuan koneksi matematis AR pada soal nomor 2 tergolong sedang.

3. Soal nomor 3

$$
\begin{aligned}
& \text { T. } \begin{array}{l}
P\left(Q^{2}+Q R^{2}=P R^{2}\right. \\
\prod_{(x+4)}+(3 x+2)^{2}=(3+-4)^{2}
\end{array} \\
& \Leftrightarrow x^{2}+8 x+16+9 x^{2}+4+12 x=9 x^{2}+24 x+16 \\
& \Leftrightarrow 10 x^{2}+4=9 x^{2}+9 x \rightarrow 02=3 x+2 \\
& \Leftrightarrow x^{2}+4=4 x \quad \quad \begin{array}{l}
0,2 x=3 x+2 \\
=3.2+2
\end{array} \\
& \Leftrightarrow x^{2}+4-4 x=0 \\
& \Leftrightarrow(x-2)^{2}=0 \\
& \Leftrightarrow x-2=0 \rightarrow x=2 \\
& =6+2 \\
& =8 \text { sat }
\end{aligned}
$$

Gambar 6. Jawaban AR pada soal nomor 3.

Setelah mengecek sebanyak 2 kali, AR menentukan bahwa soal nomor 3 berhubungan dengan beberapa konsep matematika yaitu: aljabar, teorema Pythagoras, faktor, dan persamaan.

Pada soal nomor 3, diawal AR menggambarkan segitiga. Kemudian menerapkan konsep teorema Pythagoras.Persamaan kuadrat yang dihasilkan dari teorema Pythagoras kemudian dikalkulasi dan difaktorkan hingga mendapatkan nilai $x$ yaitu 2 , kemudian menggunakan pemfaktoran sehingga didapatkan nilai dari $x$ yaitu 2 . Setelah itu, nilai $x$ disubstitusikan ke dalam sisi yang ditanyakan pada soal, yaitu panjang $Q R$, maka didapatkan panjang $Q R$ adalah 8 satuan. $A R$ tidak mampu memberikan contoh serupa dengan soal nomor 3 .

Setelah itu, JN memikirkan kembali hubungan antara soal dengan bidang lain. JN menentukan bahwa soal nomor 3 berhubungan dengan bidang pramuka. Penerapan pramuka adalah saat mengukur ketinggian sebuah pohon. Transkrip wawancara soal nomor 3

$\mathrm{P}$ : menurut anda apakah ada hubungan antara soal dengan bidang mata pelajaran 
lain/bidang lainnya?

AR: kalau pramuka mungkin ada, tapi kalau pelajaran yang lain menurut saya gak ada.

$\mathrm{P}$ : seperti apakah penerapan hubungan antara soal nomor 3 dengan pramuka?

JN : ya buat menghitung tinggi pohon.

Berdasarkan hasil tes dan hasil wawancara dapat disimpulkan bahwa pada soal nomor 3, dalam analisis kemampuan koneksi matematis AR memenuhi 4 indikator. Satu indikator yang tidak terpenuhi adalah tentang memahami hubungan diantara ide-ide matematika. Dapat disimpulkan bahwa kemampuan koneksi matematis AR pada soal nomor 3 tergolong tinggi.

Tabel 4.

Hasil analisis kemampuan koneksi matematis siswa berkepribadian sensing

\begin{tabular}{cccccccc} 
Nama & Kepribadian & Soal 1 & Soal 2 & Soal 3 & Total Skor & Rata-rata & Kategori \\
\hline AR & Sensing & 3 & 2 & 4 & 9 & 3 & Sedang
\end{tabular}

Berdasarkan hasil analisis diatas, soal nomor 1 memenuhi 3 indikator, soal nomor 2 memenuhi 2 indikator dan soal nomor 3 memenuhi 4 indikator. Terdapat 3 indikator yang sulit dipenuhi oleh AR yaitu memahami hubungan diantara ide-ide matematika; mengetahi hubungan antara bidang matematika dengan bidang ilmu lain; menerapkan hubungan antara bidang matematika dengan bidang ilmu lain. Hal ini menunjukkan bahwa siswa yang berkepribadian sensing memiliki kemampuan koneksi matematis sedang. Siswa tipe sensing sulit untuk mengetahui hubungan antara matematika dengan bidang ilmu lain, karena cenderung fokus terhadap prosedur dari materi yang terdapat pada soal, sesuai dengan karakter kepribadian sensing yaitu kepribadian yang berkaitan dengan pengetahuan prosedural. Sehingga dalam menyelesaikan soal olimpiade yang diberikan, AR hanya dapat mengetahui dan menerapkan hubungan antar matematika, sedangkan untuk hubungan antara matematika dengan bidang ilmu lain AR kesulitan. Dapat disimpulkan bahwa siswa berkepribadian sensing memiliki kemampuan koneksi matematis sedang.

\section{Kesimpulan}

Kemampuan koneksi matematis penting untuk siswa dalam menyelesaikan soal-soal matematika, utamanya soal olimpiade. Karena pada dasarnya matematika adalah bidang ilmu yang saling berhungungan baik dalam matematika itu sendiri, maupun dengan bidang ilmu yang lain. Dengan mengetahui serta mamahami hubunganhubungan yang ada dalam matematika, siswa akan lebih mudah menyelesaikan masalah dengan menerapkan hubungan yang ada didalamnya.

Berdasarkan hasil penelitian dan pembahasan diatas, diperoleh bahwa kemampuan koneksi matematis siswa tipe sensing berada di tingkat sedang, sementara kemampuan koneksi matematis siswa tipe intuiting berada di tingkat tinggi.

\section{Referensi}

Anita, I. W. (2014). Pengaruh kecemasan matematika (mathematics anxiety) terhadap kemampuan koneksi matematis siswa smp. Infinity, 3(1), 125-132.

Fadhilla, M., Ro'is, M., \& Syarif, D. (2017). Pengenalan kepribadian seseorang berdasarkan pola tulisan tangan menggunakan jaringan saraf tiruan. JNTETI, 6(3), 365-373.

Lasmawati, A. (2011). Pengaruh Pembelajaran Menggunakan Pendekatan Proses Berpikir Reflektif terhadap Peningkatan Kemampuan Koneksi dan Berpikir Kritis Matematis Siswa. Doctoral dissertation, Universitas Pendidikan Indonesia.

Lestari, K. E. (2014). Implementasi brain-based learning untuk meningkatkan kemampuan koneksi dan kemampuan berpikir kritis serta motivasi belajar siswa SMP. Jurnal Pendidikan UNSIKA, 2(November), 36-46.

Lestari, S. W. (2016). Analisis Proses Berpikir Kritis Siswa Dalam Pemecahan Masalah Matematika Pada Pokok Bahasan Himpunan Ditinjau Dari Tipe Kepribadian Ekstrovert Dan Introvert Siswa Kelas Vii Smpn 2 Sumber Cirebon. Universitas Islam Negeri 
JURNAL GANTANG. April 2019; IV(1): 61 - 70

p-ISSN. 2503-0671

e-ISSN. 2548-5547

Walisongo.

Moleong, L. j. (2009). Metodologi Penelitian Kualitatif. Bandung: PT Remaja Rosyadakarya.

NCTM. (2000). Principles adn Standard for School Mathematics. United States.

Nugraha, A. A. (2018). Analisis kemampuan koneksi matematis siswa smp pada materi sistem persamaan linear dua variabel (spldv). Suska Jurnal of Mathematics Education, 4(1), 59-64. https://doi.org/10.24014/sjme.v3i2.3897

Paneo, H. (2007). Pengaruh umpan balik evaluasi formatif dan kepribadian siswa terhadap hasil belajar matematika. Jurnal Pendidikan Dan Kebudayaan, No. 67.

Qomariah, N. (2016). Profil pemahaman siswa sma dalam memecahkan masalah persamaan kuadrat ditinjau dari perbedaan kepribadian extrovert dan introvert. Jurnal Apotema, 2, 87-95.

Rohendi, D., \& Dulpaja, J. (2013). Connected mathematics project (cmp) model based on presentation media to the mathematical connection ability of junior high school student. Journal of Education and Practice, $4(4), 17-22$.

Sudirman. (2017). Analisis kemampuan koneksi matematis siswa smp pesisir ditinjau dari perbedaan gender. In Seminar Nasional Riset Kuantitatif Terapan 2017 (pp. 131-139).

Sugiman. (2008). Koneksi matematika dalam pembelajaran matematika di sekolah menengah pertama. Pythagoras, 4(1), 56-67.

Syafmen, W. (2014). Analisis pengetahuan prosedural siswa tipe kepribadian sensing dalam menyelesaikan soal materi sistem persamaan linear dua variabel. Edumatica, 4(April), 30-36.

Trujillo, K. ., \& Hadfield, O. . (1999). Tracing the roots of mathematics anxiety through indepth interviewswith preservice elementary teachers. Collage Student Journal, 33(2),
219-232.

Warih, D. P., Parta, I. N., \& Rahardjo, S. (2016). Analisis kemampuan koneksi matematis siswa kelas viii pada materi teorema pythagoras (pp. 377-384). 